\title{
일본 정부계 금융기관 통폐합 기본방침(JBIC개혁 추가검토)
}

일본 정부 및 여당은 11 월 29 일 8 개 정부계 금융 기관 개혁 기본방침을 확정한 바, 일본정책투자은행 등 2 개 기관을 민영화하고, 공영기업금융공고(公庫) 를 지방이관하는 한편, 중소기업금융공고 등 5 개 기 관을 1 개 기관으로 통합하기로 하기로 함. 한편, $\mathrm{ODA}$ 개혁논의와 맞물려 금번 기본방침 결정에 있어 주요 이슈로 부각된 국제협력은행(JBIC)의 엔차관 부문 개혁에 대해서는 별도 유식자회의를 통해 추가 검토키로 한 바, 관련사항은 아래와 같음 .

\section{I. 정부계 금융기관 개혁 기본방침} 확정

일본 정부(총리 산하 자문기구인 경제재정자문회 의) 및 여당은 11.29 합동회의를 개최, 고이즈미 총 리가 우정민영화 개혁 이후 주요 개혁과제로 추진 해 온 정부계 금융기관 개혁의 기본방침을 확정함.
ㄷ 동 기본방침에 의한 8개 정부계 금융기관의 개혁 방안은 아래와 같음.

- 재무성 소관 ‘일본정책투자은행' 및 경산성 소 관 '상공조합중앙금고' 는 2008년부터 5 7년간 에 걸쳐 정부출자를 줄여나가 완전민영화시킴. - 총무성 소관 '공영기업금융공고(公庫)' 는 폐지 하고, 동 기능은 지자체의 채권발행기구로 이전 - 경산성 소관 ‘중소기업금융공고', 재무성 소관 ‘국민생활금융금고' 및 농수성 소관 ‘농림어업 금융공고' 는 2008년 1 개 기관으로 통합

- 내각부 소관 '오키나와진흥개발금융공고' 의 경 우 일본 정부의 현 오키나와개발계획이 종료하 는 2011년까지 현행을 유지하되, 2012년 이후 통합기관에 흡수

- 재무성 소관 '국제협력은행(JBIC)' 의 경우 에너 지 · 자원개발, 환경 분야 등 업무는 신규 통합기 관에 흡수하되, 수출입금융 업무 및 엔차관 등 $\mathrm{ODA}$ 업무에 대해서는 내년 3월까지 추가 검토 
ㅁ 금번 기본방침은 상기 개혁작업을 통해 현재 약 90조엔 수준인 정부계 금융기관의 대출규모를 2008년 절반으로 축소하기로 함.

- 일본 정부는 신규 통합기관의 업무축소 등을 포 함하여 구체적인 개혁 추진방향에 대해 계속 검 토해 나갈 예정

\section{II. 국제협력은행(JBIC) 개혁방안 추가검토(ODA청 신설 논의)}

한편, 금번 기본방침 결정에 있어 국제협력은행 (JBIC) 엔차관 부문의 JICA 통합 여부가 ODA청 신설 논의 부상에 따라 논의의 초점이 된 바, 재무 성 및 외무성이 국제협력은행 폐지 자체에 대해 반발함에 따라 관방장관 산하에 '유식자(有識者) 검토회 를 설치, 추가 검토를 거쳐 내년 3월까지 결론을 내기로 함.

당초 경제재정자문회의는 $\mathrm{JBIC}$ 의 엔차관 부문을 JICA로 통합하여 외무성 산하에 두는 방안 및 $\mathrm{JBIC}$ 엔차관 부문과 $\mathrm{JICA}$ 를 합쳐 수상직할 신규 기관(ODA청)으로 구성하는 방안을 함께 제시

- 이에 대해 재무성은 일본 기업의 해외진출 촉진 을 위한 수출금융 및 엔차관을 함께 담당하는 현 JBIC 체제의 유지를 주장하고, 수상직할 신 규기관(ODA청)이 창립될 경우 $\mathrm{ODA}$ 관련 권한 상실을 우려한 외무성도 현 JBIC의 유지를 희망 ㅁ 이와 같이 재무성, 외무성 양측 모두 JBIC 유지를 희망함에 따라 추가 검토 결과는 알 수 없는 상황
- 일본 정부내 ODA청 설치 구상은 2001년 일본 정부 행정개혁시에도 제기된 바 있으나 외무성 등의 반발로 무산된 바 있음.

\section{III. 일본 언론 평가}

일본 언론은 금번 기본방침 결정에 대해 그동안 비대한 업무규모 및 정경유착 등 부작용이 지적되 어 온 정부계 금융기관 개혁의 중요방향이 결정된 것으로 평가

- 닛케이신문은 고이즈미 총리의 공적금융 개혁 에 있어 우정민영화 개혁이 입구에서의 개혁이 었다면, 정부계 금융기관 개혁은 출구에서의 개 혁인 바, 정책적 역할이 끝난 공적금융의 출구 개혁을 위해서는 보다 엄중한 목표가 필요하다 고 주장

- 도쿄신문은 전후 복구기 및 고도성장기를 통해 정부계 금융기관의 정책금융 역할이 컸으나, 현 재 시장에 자금이 넘쳐나는 상황에서 그 역할이 축소되고 있으며 대범한 통폐합이 필수적이라 고 주장

- 요미우리신문은 중앙관청이 정부계 금융기관의 업무 및 인사에 관여해 옴에 따라 그동안 업무 가 비대화되어 왔다고 지적

ㅁ 또한, 일본 언론은 금번 기본방침이 정부계 금융 기관의 존폐에 관한 조직론에 지나지 않는 바, 향 후 업무의 슬림화 및 특성화 등 개혁 '내용'에 대한 보다 면밀한 검토가 필요하다고 지적 
- 중소기업 대상 정책금융의 경우 심사를 엄격히 강화하고, 대기업 대상 해외투자금융의 경우 보 증업무에 한정하는 등의 방안을 제안

마울ㄹㄹ 정부계 금융기관의 민영화, 통폐합 등 추 진과정에서 현재 일반은행보다 높은 수준인 불량 채권율, 정부개입이 적어짐에 따른 자금조달이 여 의치 않을 수 있는 문제 등에 대한 해결방안도 검 토되어야 할 것으로 지적함.

- 또한, 정부계 금융기관 수뇌부에 중앙관청 관료 가 진출하는 인사관행의 발본적 개혁이 필요하 다고 지적
만편, 국제협력은행(JBIC)의 엔차관 부문 추가 검 토와 관련하여, 1999년 일본수출입은행과 해외경 제협력기금이 JBIC로 통합되었으나, 업무내용, 직원구성이 변화가 없는 단순한 통합에 지나지 않 았는 바, 금번 검토시에는 충실한 개혁방안이 논 의되어야 한다고 주장

- 동 관련 아사히 신문은 외무성, 재무성, 경산성 의 원조부문을 집약하여 수상직할로 원조청을 신설하고, JBIC 엔차관 부문과 JCA를 통합한 신규기관을 동 관할로 할 것을 주장

[자료:주일본 대사관] 